\title{
INTERNATIONAL BUSINESS BOOKS/PUBLICATIONS RECEIVED BETWEEN APRIL 1 AND JUNE 13, 1997
}

Readings in International Business. Seung H. Kim, Suk H. Kim, Duane Kujawa, and Gregory Ulferts, editors. Lanham, MD: University Press of America, 1997 (soft) \$47.00 USD.

Privatization and Competition in Telecommunications: International Developments. Daniel J. Ryan, editor. Westport, CT: Greenwood Publishing Group Inc., 1997 (hard) \$65.00 USD.

Methods and Data Analysis for Cross-Cultural Research. Fons van de Vijver and Kwok Leung. Thousand Oaks, CA: Sage Publications, Inc., 1997 (soft) $\$ 19.95$ USD.

Business Guide to Modern China. Jon P. Alston and Yongxin He. East Lansing, MI: Michigan State University Press, 1997 (soft) \$29.95 USD.

Information Technology, Development and Policy. Edward Mozley Roche and Michael James Blaine, editors. Brookfield, VT: Ashgate Publishing Company, 1997 (hard) \$67.95 USD.

The Special Economic Zones of China and Their Impact on Its Economic Development. Jung-Dong Park. Westport, CT: Greenwood Publishing Group Inc., 1997 (hard) \$65.00 USD.

Imitation to Innovation: The Dynamics of Korea's Technological Learning. Linsu Kim. Boston, MA: Harvard Business School Press, 1997 (hard) $\$ 35.00$ USD.

Quantitative Aspects of Post-War European Economic Growth. Centre for Economic Policy Research. Bart van Ark and Nicholas Crafts, editors. New York, NY: Cambridge University Press, 1997 (hard) \$69.95 USD.

Financing China Trade and Investment. Kui-Wai Li, editor. Westport, CT: Greenwood Publishing Group Inc., 1997 (hard) \$69.50 USD.

Mexican Banking and Investment in Transition. John A. Adams, Jr. Westport, CT: Greenwood Publishing Group Inc., 1997 (hard) \$69.50 USD.

The Ostrich and the EMU: Policy Choices Facing the UK. London, UK: Centre for Economic Policy Research, 1997 (soft) £7.50, \$12 US.

Pandemonium: Towards a Retro-Organization Theory. Gibson Burrell. Thousand Oaks, CA: Sage Publications, Inc., 1997 (soft) \$65.00 USD. 